\title{
Response of farmers and procurement agencies to minimum support price in Dharwad and Haveri districts
}

\author{
C. MURTHY, VILAS KULKARNI AND BOURAMMA P. KERUR
}

Received : 13.06.2015; Revised : 08.08.2015; Accepted : 09.09.2015

\begin{abstract}
The minimum support prices are a guarantee price for their produce from the Government. The major objectives are to support the farmers from distress sales and to procure food grains for public distribution. Though the scheme is in operation for major agricultural commodities for the past several years, the farmers using it and getting benefit out of it is not significant. Still many farmers do not go for selling their produce through procurement agencies though there is substantial difference in prices. This study would throw light on reasons for such behavoiur with the objective to study the response of farmers to MSP scheme for the selected agricultural commodities and to study problems faced by procurement agencies in operating MSP scheme. Two districts namely Dharwad and Haveri were selected for the study. From each district three major markets were selected. The total sample size was 540 . The primary data was collected from the selected respondents through personnel interview method with the help of pre-structured schedule. The study revealed that in Dharwad and Haveri districts only about 28 to 35 per cent of farmers were aware of MSP scheme. The major source of information were neighbors/friends, news paper/TV/radio and APMCs. Important problems faced by all the procurement agencies were malpractices in issue of certificate by agents to farmers and selling it under MSP in the name of farmers and lack of staff.
\end{abstract}

KEY WORDS : Farmers, Procurement agencies, Minimum support price

How to cite this paper : Murthy, C., Kulkarni, Vilas and Kerur, Bouramma P. (2015). Response of farmers and procurement agencies to minimum support price in Dharwad and Haveri districts. Internat. J. Com. \& Bus. Manage, 8(2) : 188-194.

\section{MEMBERS OF THE RESEARCH FORUM}

Correspondence to:

C. MURTHY, Department of Agribusiness Management, College of Agriculture, University of Agricultural Sciences, DHARWAD (KARNATAKA) INDIA

Authors' affiliations:

VILAS KULKARNI AND BOURAMMA P. KERUR, Department of Agribusiness Management, College of Agriculture, University of Agricultural Sciences, DHARWAD (KARNATAKA) INDIA 